\title{
Questioning Cloning with Genealogy
}

\author{
Emmanuel Ifeanyi Ani \\ Department of Philosophy and Classics, University of Ghana, Legon, Greater Accra, Ghana \\ Email: mabrowest@yahoo.com, emmanani@ug.edu.gh \\ Received May $4^{\text {th }}$, 2013; revised June $4^{\text {th }}$, 2013; accepted June $11^{\text {th }}$, 2013
}

\begin{abstract}
Copyright (C) 2013 Emmanuel Ifeanyi Ani. This is an open access article distributed under the Creative Commons Attribution License, which permits unrestricted use, distribution, and reproduction in any medium, provided the original work is properly cited.
\end{abstract}

\begin{abstract}
I evaluate a hypothetical society of human clones. Cloning implies the production of exact copies of an organism from a replication of one of the organism's cells without any recourse to the genealogical protocol of male and female reproduction. I thus pose the question: Can we regard a cloned copy of Mr. James as a son of Mr. James or Mr. James once again? I consider certain implications of human cloning to the concepts of individual uniqueness, and thus of genealogical family tree and the future of the naming and identification of humanity?
\end{abstract}

Keywords: Cloning; Genealogy; Individual Uniqueness; Personal Identity; Genetic Engineering; Family; DNA; Hypothetical Society; Social Organization

\section{Introduction}

This article is a partial justification of the non-binding United Nations Declaration banning all forms of human cloning as going against human dignity. ${ }^{1}$ The justification provided by this article is limited to an evaluation of the outcome of a hypothetical society of human clones to genealogy. The concept of genealogy is central to the concepts of individual, family and societal identity. In a sense, it constitutes the emergence of organized human society, beginning from the basic unit of society which is the family. The family is founded on the concepts of conjugal love and procreation. Procreation is assumed a natural result of conjugal love. But in societies where procreation is held to be sacrosanct, infertility is socially debilitating. Some infertile couples go as far as adopting children. In this context, the advent of genetic engineering wherein infertile parents can still have biological offspring is hailed as a positive development. It is seen as capable of giving happiness to infertile couples.

However, human cloning, in methods as well as in effect, appears to sit in unhealthy juxtaposition to the very concept of genealogy. And since genealogy is foundational to the concepts of individual uniqueness, identity and personhood, then cloning raises very grave questions in the context of man and humanity.

\section{The Concept of Genealogy}

Genealogy refers to the study of family pedigree (Lorimer, 2000: p. 413) or family history; the decent of a person or family from an ancestor, generation by generation. It originated as an oral tradition, the ancestry of important members of society, and often written down (in the Bible for instance). Since 16th century, records of family descent have been strictly kept in many countries, so that many people in the world could trace their ancestry if they wished. A chart showing genealogical

${ }^{1}$ This document is accessible on

http://www.bioeticaweb.com/content/view/1267/765/lang,es/ descent is a pedigree, this may be crucial in establishing a matter of inheritance. In countries where wealth and position are commonly inherited, genealogy is very important. Even where legal and social reasons are fewer, people still attempt to trace their family tree (Crystal, 2000: p. 452).

It is obvious from the above that genealogy is central to the concept of family and society identity. Genealogy can trace the origin of a particular society, or group of societies, to a common ancestor.

In chronological terms, therefore, we can say that genealogy can lead us back to the origin of many human societies. Social groups and communities with common ancestry form ethnic groups and nations with distinct cultural identity. It follows then that the major races of the world are genealogically founded. So genealogy as a concept, an instrument or a tool, cannot be overemphasized in the concept of human organization.

\section{Family as Vehicle of Genealogy}

The concept of genealogy is worked out precisely in the context and horizon of - and through the instrumentality of the family. Also known as family tree, genealogy presupposes the existence and succession of a historical chain of families or of the family system. The family here refers not just to the group formed by husband, wife and children (nuclear) but a wider category of relatives, including grandparents, uncles, aunts, cousins (extended family) which, in particular, show that the concept of descent has already exceeded a generation.

\section{Cloning}

This involves producing an animal or plant artificially from the cell of another animal or plant in which case the animal or plant becomes identical with the animal or plant from which cell it was artificially produced. Thus a clone is an animal or plant which has the same genes as the original from which it was produced (Madu, 2003: p. 26). Cloning is done by finding 
a donor egg, sucking out the nucleus of the egg (the DNA), injecting a cell from the person you wish to re-create or copy as the new nucleus of the egg, and encouraging this to grow. In this case a dead cloned child can be re-created. By the definition of cloning, the outcome should be exactly the same as its source. For deeper appraisal of the merits and dangers of human cloning and its relation to genealogy, let us briefly examine three basic types of cloning.

\section{Embryo Cloning}

Cloning also occurs naturally in living organisms including humans. What is termed monozygotic or identical twins are clones of each other. The identical twins have the same genetic information due to the division of an embryo early in development which produces two identical embryos that mature to identical twins.

Embryo method of cloning resembles the natural, twin method in that the embryo is divided into two or four identical cells, separated and placed in conditions suitable for growth, usually a uterus. The twins, triplets or quadruplets thus formed have identical DNA.

\section{Somatic Cell Nuclear Transfer or Adult DNA Method of Cloning}

This method employs the technique used in cloning the sheep called Dolly. It entails nuclear replacement. It involves the removal of DNA from an adult ovum and replacing it with the DNA of a cell removed from the adult animal intended for recreation (Donnellan, 2004: p. 14).

\section{Therapeutic Cloning Method}

This uses the same cloning procedure as the second or adult method, except that the clonal embryo, instead of being implanted into a womb, is used to generate a stem cell. These stem cells can be cultured in Petri dishes and used to generate therapeutic tissues or human spare parts. This is to improve regenerative medicine (Donnellan, 2004: p. 15).

\section{Philosophical Issues in Genetic Engineering}

One philosophical question that emerges concerning genetic engineering especially on the issue of cloning is: What is the status of a cloned being? Will it possess spirit or soul like normal beings? A second question is: Is it ethical or moral to experiment on humans?

An even more grave implication of the success of cloning is the polarization of society into clones and non clones. In other words, society will be categorized into natural and artificial people. In this context, what will be the attitude of natural men toward artificial ones? Even more importantly, what will be the attitude of artificial men toward the normal human beings? Is it likely that natural people will see their artificial colleagues as supermen, women or second class citizens? Will a segregation that will result from this polarization not be of a more enduring category than previous segregations based on race, religion and ideology? Molecular Biologist Lee M. Silver believes that unlike Aldous Huxley's Brave New World, where a totalitarian government controls all of the genetic enhancements (they actually use eugenics instead of direct genetic modification) in society, the use of gene therapy to design children will be spread through what he calls "free market eugenics" (Silver, 2009: p. 315). Wealthy families will opt to design their child with ge- netic advantages because other families are doing so, and everybody wants to provide their newborn child with the best opportunities in life, with a leg up on the competition.

The greatest fear for Silver is that we will design so many children with germline gene therapy that the families wealthy enough to design their children will pass down these enhanced traits to future generations. This gene therapy will obviously cost money, and the less wealthy families will be left to procreate naturally, and introduce their children into the world comparatively disadvantaged from their first breath.

The impact on society will be a new alignment of classes, no longer will we separate people by their ethnic differences, the new division will be between what Silver calls "the naturals" and "the GenRich" or the genetically enhanced. The major worry here is that the "genetic gulf" between these two classes will become so wide that humans will become separate species (Silver, 2010: p. 313).

Back to the issue of life, the development of stem cells might need to address a vital question: When (in the making of stem cells) does life begin? The development of stem cells involves at a certain stage the prevention of embryo or fetus from developing into a full human being, resulting in body tissues or body spare parts for medical and surgical uses. So a further question emerges: Should life be terminated at any stage of development of human life? Has the embryo, from which destruction stem cells are extracted, any fundamental right to life?

Pro-stem cell scholars are of the view that the embryo from which the stem cell is extracted is just a body tissue. And more so, since these embryonic stem cells are to be used as spare parts for therapeutic purposes to save and prolong life, they do not see why human cloning should not be promoted (Eboh, 2005: p. 138). But pro-life scholars argue that life begins at conception and so it is unethical to terminate life at any stage of human development.

\section{...a human embryo cultured till the stage of blastocyst is a human being in so far as it contains a complete genome and all that is needed to develop into an adult human be- ing. To extract stem cell from embryo is to destroy life in it, which is the same thing as destroying human life (Eboh, 2005: p. 138).}

For these scholars, the human life that comes from blastocyst has value and dignity and so it deserves respect just as much as life already born. So a problem arises as to whether respect for the beginning of human life allows the use of embryos or fetuses for any other purpose except bringing them to term. For pro-life scholars the answer is in the negative (Eboh, 2005: p. 138). The Vatican agrees with this stance in that human cloning regardless of its objectives is contrary to the dignity of man and his right to life (Eboh, 2005: p. 138).

The only argument in support of cloning has been utilitarian in nature, namely that scientific breakthrough serves a useful purpose and this platform should define morality. There is no doubt that research and experimentation have contributed immensely to bring about improved quality of life for human beings. Yet the need for moral safeguards cannot be overemphasized, for science without conscience can lead to the ruin and destruction of mankind. According to Ekennia:

Scientists researching into regenerative medicine should look beyond huge financial gains and businesses promised by this extreme research programme and focus more on 
the value and dignity of the human person at all stages of its formation. The ethical questions should act as litmus test for all genetic engineering procedures (Ekennia, 2003: p. 145).

Eboh (1999: p. 78) sees this as important since it involves "engineering the engineer". Considering if science should receive unconditional consent in everything however dangerous merely on the basis of freedom of inquiry, Ozumba (2003: p. 206) poses the question: Is it ethically permissible to indulge scientific inquiry in carrying out any kind of inquiry in the spirit of free inquiry? This is against the background of the argument that without free inquiry, science could not have achieved so much for the comfort and utility of man. But we may have to consider that no freedom is absolute, and the right to free inquiry should be a qualified freedom like other freedoms.

Equally dilemmatic will be a hypothetical society where parents can have children without the instrumentality of sexual intercourse. The supportive argument here is that conjugal love has nothing to do with procreation, after all, the lower animals procreate as a matter of natural instincts and not because they love (Madu, 2003: p. 24). But when we separate conception of a child from conjugal love, we only succeed in biologizing and depersonalizing human marriage (William, 2002: p. 5).

Cloning poses greater difficulties in the context of sex selection. It has been argued that knowing and selecting the sex of their children can guarantee the fulfillment and happiness of parents. And since marriage craves for happiness in life, sex selection becomes an avenue for this (Madu, 2003: p. 26). But the natural distribution of sex by nature could be meant to serve a balancing goal. Will sex selection in patriarchal cultures not lead to imbalance of male and female? In societies where male issues are preferred to female ones, will sex selection not create grave problems in the population structure? But let me briefly examine the position of cloning with regards to genealogy and individual identity.

\section{The Question of Genealogy}

The prospect of human cloning has serious implications for the concept of genealogy. Admittedly, there are merits to be derived from cloning, like the renewal of damaged body cells (stem cells). It can remedy infertility through adult cloning, and with cloning, cultures with strong conceptions of genetic inheritances to wealth can safeguard this tradition.

However, cloning runs into serious juxtaposition to genealogy. This juxtaposition is demonstrated in the concept of offspring. As discussed, a man can have a cell of his body engineered to produce a human being exactly identical to him in everything. Can we regard this human being as his son, or is the clone simply the man from whose body it came?

This is because a son is supposed to be a sexual combination of two distinct DNA sets. The biological product of the fusion of these two sets of DNA (from a man and woman) gives rise to a uniquely arranged set of DNAs and thus a unique human being with a distinct personality and individuality. This new person embodies features and resemblances of both progenitors, but is not a complete replication of either. That is, a natural, sexually reproduced baby resemblances its father in some respects and its mother in some other respects, even resembles the father's father or mother or the mother's father or mother as well as grandparents in some other respects; but is neither com- pletely identical to the father, nor completely identical to the mother, nor completely identical to any of their parents or grandparents; but is a distinct human being imbued with uniqueness, individuality and personality. Boethius (1345: p. 64) and Aquinas (1981: p. 29) see this unique and separate person as embodying an autonomous and incommunicable aspect which makes him entirely distinct from all others. Thus on this note, no son is exactly identical to his father.

However, a clone is entirely identical to its original. Indeed, I use the word "original" because I hesitate to designate the original copy as "father". This is because a clone is not at all unique from its original. A clone made from Mr. James is nothing but Mr. James once again. This clone cannot be a son to Mr. James, only himself photocopied, re-manufactured or recycled. This clone has one and the same DNA as Mr. James, but a son to Mr. James must have a distinct DNA from both Mr. James and his wife or whoever is the mother.

We have seen that a man and woman must beget a son/ daughter who has a distinct and unique DNA, in other words, a unique human being imbued with uniqueness, individuality and personality. And if a genealogy or family tree is made up of a succession of sons and daughters across generations, then uniqueness, individuality and personality lie at the very root of the concept of genealogy or family tree, and thus provide the platform for its meaning.

It follows that since a clone is an exact copy of its original, it has no uniqueness, individuality or personality, and since it has no uniqueness or personality distinct from its original, then it has no father/mother, and therefore no family descent. By extension, it has no family tree and no genealogy. Also by extension, a hypothetical community of clones is a community of people with no individuating uniqueness, personality, no family descent, and no genealogy. If we could imagine this community, filled as it were with only exactly identical clones, then it is not difficult to see that there is no difference between one individual and another.

In other words, there is no individual differentiation. But without individual differentiation there can be no social and political organization. Hence if we conceived a continent filled with identical clones, it will be difficult to distinguish nations, ethnicities, communities, and states. Why is this? Because many people in such a hypothetical world are one and the same person. But social and political organization presupposes the diversity and resultant identification that result from uniqueness, individuality and personality of distinct persons. Organizational administration (of whatever form) will not make much sense in a routine conflation of the identities of organizational roleoccupants. By blurring issues of uniqueness, individuality and personality/personhood, cloning is an anti-thesis to social organization and a thesis for a sort of state of nature.

The strongest objection to this forecast is that man is a product of both nature and nurture, and that because of nurture, identical clones, like identical twins, would in any case end up as different personalities. The first problem with this objection is that of a false analogy between clones and identical twins. Unlike clones, identical twins are not exactly identical with their parents. Identical twins might emerge from the splitting of a single fertilized egg, but such a fertilized egg is a product of two individuals. Secondly, we may borrow a little lesson from the identity or identification difficulties we encounter in relating with identical twins. We would recall that this difficulty is magnified by the fact that it is only people in prolonged and 
regular touch with identical twins (such as their parents and siblings) who are able to overcome it. This is because we can distinguish identical twins only by means of their character or behavioral differences. The special problem with human character is that it is not immediately discernable. Even more problematic is the fact that much of our transactions are not with people whose character we have come to know and familiarize. A third difficulty is that in cases where we are familiar with a set of twins, one way we could distinguish between them will be their differences in mannerism. But we cannot rely on this because they could well have the same mannerisms if they went through similar socialization processes. Mannerism results largely from socialization, and excepting cases of upbringing in radically different social settings, there is nothing to show that the very first statement (or couple of statements) of an identical twin or clone will clearly distinguish her. But our normal case scenario clearly does not involve identical people being brought up in radically different and far-off cultures with different social mannerisms and methods of greeting/exclamation. In any case, the general business of social organization/administration of society is simply unable to afford the time luxury of identifying clones by long-drawn character differences alone. We will recall that administration and management of human beings regularly involves prompt identification for the meting out of reward for good conduct and punishment for offensive behavior. Thus, the objection that nurture will frequently and immediately help us to differentiate clones might be overplayed.

If a clone has exactly the same set of DNA as its original cell, then we do not have an assurance that those identical cells will not all possess one talent, one gift, one aptitude, one intelligence quotient (IQ), etc. We may recall that the great variety of unique talents, aptitudes and gifts embodied in humanity as a result of the unique distributive power of natural reproduction, make up the complexity of contributions that produce civilization. If we are to picture a hypothetical world of identical clones instead of innumerably talented and uniquely gifted people all imputing at innumerable levels, dimensions and qualities, then we can possibly picture an antithesis to a great civilization as we currently know it.

\section{Conclusion}

It is obvious that cloning promises prospects such as renewal or replacement of damaged body cells (stem cells), remedy to infertility (through adult cloning) and resolution of problems of genetic inheritance. But these positive prospects must be viewed within the context of broader dangers. One of these is genealogy, which provides the platform for determining individual uniqueness, identity and personality. Moreover, the cross-fertilization afforded through bi-sexual reproduction gives rise to variety of talents and gifts, which supply the variety, initiative and complexity that inform civilization and sociopolitical organization. Thus, genealogy lies at the very root of man's social cohesion. A hypothetical society of clones is uneasily juxtaposed to individual uniqueness, personal identity, and thus to social organization, human parentage and civilization as currently cast.

\section{Acknowledgements}

The author thanks Rev. Fr. Dr. Patrick Udenna Ezefunamba for bringing his attention to thinking about issues in genetic engineering, and thus, of implications regarding cloning.

\section{REFERENCES}

Aquinas, T. (1981). Summa theologiae. Maryland: Christian Classics. Boethius, A. (1345). De Persona et duabus naturis. 3. Patrologia Latina $(P L), 64$.

Crystal, D. (Ed.) (2000). The cambridge encyclopedia (4th ed.). Cambridge: Cambridge University Press.

Donnellan, C. (2004). Genetic modification (Issues). Montana: Independence Educational Publishers.

Eboh, B. O. (1999). Ethical implication of genetic engineering. Arts and Social Sciences Quarterly Journal of Inter-University Friendship Association, Federal University of Technology, Owerri, 1.

Eboh, B. O. (2005). Living issues in ethics. Nsukka: Afro-Orbis Publishing Co. Ltd.

Ekennia, J. N. (2003). Bio-medical ethics: Issues, trends and problems. Owerri: Barloz Publishers Inc.

Iroegbu, P. (2000). Kpim of personality; Treatise on the human person (respect, solidarity, liberty). Nekede, Owerri: Eustel Publications Nig.

Lorimer, L. T. (Ed.) The new Webster's dictionary of the english language. International Edition.

Madu, J. E. (2003). The paradox of the "one" and the "many" in religion. Awka: Globe Communication/Jude Emeka Madu.

Ozumba, G. O. (2003). Medical ethics: Background and contemporary issues. Calabar: Pyramid Publishers.

William, C. (2002). Recent moral thinking on human genetic engineering. Doctrine and Life.

https://www.dominicanpublications.com/our-journals/doctrine-a-life. html 